УДК 658.152

(C) 2014

Воловик Д. В., аспірант

(науковий керівник - доктор економічних наук О. I. Дачій)

Дніпропетровський державний аграрно-економічний університет

\title{
РОЗВИТОК СИСТЕМИ УПРАВЛІННЯ РЕСУРСНИМ ПОТЕНЦІАЛОМ АГРАРНИХ ПІДПРИЕМСТВ
}

\section{Рецензент - доктор економічних наук Л. І. Катан}

У статті визначено, щзо ефективне управління ресурсним потенціалом аграрних підприємств повинно являти собою гнучку систему, шо буде пристосовуватись до ринкових умов та забезпечувати загальний розвиток підприємства. Проведений аналіз напрямів розвитку ресурсного потенціалу аграрного підприємства $і$ запропоновано основні напрями формування системи ефрективного управління використанням ресурсного потенціалу, для розробки і впровадження якої необхідно досягти високого рівня інформаційноаналітичного забезпечення управління, щзо є необхідною умовою розвитку аграрного сектора економіки.

Ключові слова: аграрне підприємство, ресурсний потенціал аграрного підприємства, управління ресурсним потенціалом підприємства, система ефективного управління ресурсним потенціалом підприємства.

Постановка проблеми. Система управління ресурсним потенціалом створюється та впроваджується на аграрному підприємстві як засіб, що забезпечує проведення певної політики і досягнення поставленої мети 3 питань якості з урахуванням конкретної діяльності і специфіки підприємства. Вона повинна забезпечувати максимальну продуктивність ресурсів, які використовуються в процесі досягнення підприємством поставлених цілей 3 урахуванням можливих змін, обумовлених нестабільністю економічного середовища в умовах лібералізації та посилення конкуренції на внутрішньому ринку харчових продуктів для того, щоб підтримувати належний рівень ресурсного потенціалу, задовольняти вимоги суб' єктів ринку.

Підвищення ефективності управління ресурсним потенціалом аграрних підприємств, забезпечення його раціонального використання значною мірою пов'язано 3 проведенням якісних змін у складі ресурсів та з підвищенням ефективності в їх управлінні. Завдання підвищення ефективності управління ресурсним потенціалом підприємств полягає, насамперед, у вдосконаленні використання та управління ресурсами аграрного підприємства й у підвищенні їх цілісності, яка проявляється у їх тісному взаємозв'язку. Ресурсам підприємства повинен бути притаманний відповідний спектр функціональних характеристик, на основі яких має забезпечуватись компенсація їх дефіцитних властивостей [2].

Аналіз останніх досліджень і публікацій, у яких започатковано розв'язання проблеми. Дослідженням побудови ефективності системи управління ресурсним потенціалом на підприємстві, аналізу іiі впливу на конкурентоспроможність підприємства присвятили роботи як провідні зарубіжні вчені (Е. Демінг, Дж. Джуран, Г. Тагуті), так і вітчизняні. Зокрема, дане питання досліджували Д. Г. Гольцев, Є. А. Гончаров, Ю. Б. Кабаков, В. М. Корешков, І. М. Ліфіц та ін. $[1,2]$.

Чимало науковців торкаються питань вивчення потенціалу аграрного підприємства та його ефективного управління, серед них: О. В. Ареф'єва, А. В. Борисов, Ю. М. Воробйова, Н.М.Гуляєва, С. О. Іщук, Т. В. Калінеску, Н. С. Краснокутська, В. О. Лук'яних, В. С. Новицький, I. М. Писаревський та інші. Більшість наукових робіт вченихекономістів відзначається важливістю проблем ефективного управління ресурсним потенціалом підприємства, його відтворення, всебічної модернізації і високоефективного використання, а також оптимального забезпечення всіма ресурсами, що належить до найбільш гострих, складних і надзвичайно актуальних не лише в науковому, а й у практичному плані. Однак водночас недостатньо уваги приділено проблемам упровадження таких систем на вітчизняних підприємствах $[3,4]$.

Мета і завдання досліджень. Метою статті $\epsilon$ визначення методичних основ удосконалення системи управління ресурсним потенціалом аграрних підприємств та обгрунтування теоретикометодичних засад і концептуальних підходів щодо вдосконалення механізму управління формуванням і використанням ресурсного потенціалу аграрних підприємств.

Для досягнення поставленої мети були визначені та вирішувалися такі завдання: 


\section{СТОРІНКА МОЛОДОГО ВЧЕНОГО}

- розкрити сутність та умови формування ресурсного потенціалу аграрних підприємств;

- систематизувати методологічні підходи до обгрунтування системи наукового забезпечення управління ресурсним потенціалом в аграрному секторі;

- опрацювати концептуальні підходи до формування системи ефективного управління, використовуючи ресурсний потенціал;

- визначити ступінь впливу факторів на ефективність управління ресурсним потенціалом в аграрному секторі економіки.

Матеріали і методи досліджень. Теоретичною та методичною основою дослідження були основні положення економічної теорії, теорії управління, наукові праці вітчизняних i зарубіжних учених із проблем теорії та практики удосконалення економічних взаємовідносин у використанні ресурсів в аграрних підприємствах, системного аналізу управління формуванням і функціонуванням ресурсного потенціалу в умовах ринку. Завдяки застосуванню системного підходу обгрунтовано необхідність комплексного використання механізмів управління ресурсним потенціалом, що забезпечує узгоджене функціонування його складових. Використовувалися такі методи дослідження: порівняльного аналізу (вивчення методичних підходів, концепцій, розробок, пропозицій провідних вітчизняних і зарубіжних учених); історичний метод (дослідження еволюції механізму впливу управління ресурсним потенціалом на розвиток аграрних підприємств із метою виявлення закономірностей формування цього механізму); абстрактно-логічний (теоретичні узагальнення та формулювання висновків).

Результати досліджень. В умовах постійних економічних змін підприємствам слід звертати значну увагу на розширення та поглиблення досліджень в галузі управління ресурсним потенціалом. Ефективне управління ресурсним потенціалом аграрних підприємств повинно являти собою гнучку систему, що буде змінюватись, пристосовуватись до ринкових умов, водночас виробляти якісну продукцію та забезпечувати загальний розвиток підприємства [5]. Першочерговим етапом у побудові системи ефективного управління ресурсним потенціалом $є$ встановлення місії. Ставиться глобальна мета діяльності підприємства, яка відбиває призначення підприємства, його роль у суспільстві та забезпечення власних конкретних інтересів. Після встановлення місії необхідно встановити конкретні цілі діяльності. У такому разі ефективне управління ресурсним потенціалом повинно бути спрямоване на виконання не тільки основної місії підпри- ємства, але і його цілей, які виходять 3 його місіі.

Вагоме значення у формуванні ефективного управління ресурсним потенціалом підприємств аграрного сектора економіки має аналіз факторів зовнішнього та внутрішнього середовищ. Зокрема, аналіз зовнішнього середовища має на меті виявити потенційні загрози та можливості, 3 якими підприємство може зустрітися в майбутньому. Основними 3 таких факторів $\epsilon$ : економічні, політичні, ринкові, фактори технології, конкуренції, міжнародні, соціальні. Результатом такого аналізу може стати перелік майбутніх загроз та можливостей з урахуванням їх значення i ступеня впливу на підприємство.

Першочерговим етапом у побудові ефективного управління ресурсним потенціалом є встановлення місії. Ставиться глобальна мета діяльності підприємства, яка відображає призначення підприємства, його роль у суспільстві та забезпечення власних конкретних інтересів. Після встановлення місії необхідно встановити конкретні цілі діяльності. При цьому ефективне управління ресурсним потенціалом повинно бути спрямоване на виконання не тільки основної місії підприємства, але і його цілей, які виходять 3 його місії [2].

Оцінювання ефективності використання ресурсів $є$ наступним етапом формування системи ефективного управління ресурсним потенціалом. Така оцінка повинна містити певний набір показників та критеріїв для визначення оптимального напряму управління ресурсами підприємства, що дасть можливість з'ясувати, як працює підприємство, чи досягаються поставлені цілі, як зміни та вдосконалення в процесі управління впливають на ресурсний потенціал. Для оцінювання ефективності необхідна система показників, яка враховувала б фактичну динаміку використання ресурсів підприємства. При цьому економічний ефект досягається за рахунок виробництва якісної продукції та отримання прибутку [6].

Управління ефективністю ресурсного потенціалу необхідно розглядати як допоміжний етап, який повинен містити такі напрями, як якість управління та управління результатами. Якість управління передбачає, в першу чергу, культуру управління, в межах якого підприємство прагне досягнути поставлених цілей. Даний напрям повинен формуватися під впливом ефективної системи мотивації та контролю за чіткого визначення цілей і пріоритетів розвитку підприємства й однозначному поділі повноважень і відповідальності. Управління результатами діяльністю повинно містити сукупність систематичних проце- 


\section{СТОРІНКА МОЛОДОГО ВЧЕНОГО}

дур і підходів, що використовуються для оцінювання результатів діяльності підприємства та зворотного впливу 3 метою їх покращання. Прийняття рішень має відповідати загальним вимогам, що висуваються до будь-яких управлінських рішень. Вони мають бути обгрунтованими, цілеспрямованими, кількісно та якісно визначеними, правомірними, оптимальними, своєчасними, комплексними й гнучкими. Тільки за умов дотримання цих принципів прийняті рішення будуть виконувати керуючу (сприяти досягненню поставлених цілей), координуючу (узгоджувати окремі дії, рішення, діяльність окремих фахівців та підрозділів) та мобілізуючу (активізація виконавців) функції.

Кінцевим етапом побудови системи ефективного управління ресурсним потенціалом підприємств є контроль. Контроль, як важливий та необхідний етап, повинен містити застосування системи спостереження і перевірки відповідності використання ресурсів підприємства встановленим стандартам та іншим нормативам, прийнятим планам, програмам і оперативним управлінським рішенням, а також виявлення допущених відхилень від прийнятих принципів організації та ведення господарства [7].

Система ефективного управління ресурсним потенціалом підприємств дає можливість також визначити, які внутрішні його характеристики послаблюють результативність досягнення ефективності в процесі управління ресурсним потенціалом. Ефективність досягається за рахунок реалізації послідовних дій, які здійснюються під час управління. Забезпечення внутрішньої рухливості та гнучкості підприємства $\epsilon$ основою ефективного управління ресурсним потенціалом підприємства та досягнення його загального еконо-

\section{БІБЛІОГРАФІЯ}

1. Ареф’єва О. В. Економічні засади формування потенціалу підприємства / О. В. Ареф’єва, Т. В. Харчук // Актуальні проблеми економіки. 2012. - №7(85). - С. 71-76.

2. Безус П. І. Моделювання процесу економічного розвитку виробничого підприємства: автореф. дис. на здобуття наук. ступеня канд. екон. наук : спец. 08.00.11 / Київ. нац. економ. ун-т ім. Вадима Гетьмана / П. І. Безус. - К., 2007. - 19 с.

3. Гуткевич С. О. Дослідження факторів інвестування / С. О. Гуткевич // Актуальні питання економіки : теорія і практика / С. О. Гуткевич ; гол. ред. - д.е.н. В. Є. Новицький. - К. : Вид-во Свроп. ун-ту, 2011. - Вип. 1. - С. 5-8.

4. Краснокутська Н. С. Потенціал підприємс- мічного розвитку.

Основними напрямами формування системи ефективного управління використанням ресурсного потенціалу $\epsilon$ : забезпечення раціонального використання земельних, водних та інших природних ресурсів в аграрному секторі, а також основних матеріальних засобів; застосування ресурсозберігаючих технологій; ефективне використання трудових ресурсів; забезпечення стабільності формування й ефективності використання внутрішніх і зовнішніх фінансових ресурсів; розвиток інноваційних процесів і впровадження їх результатів у забезпечення інтенсифікації аграрного виробництва та продовольчої безпеки держави. Для розробки й успішного впровадження даної системи у життя необхідно досягти високого рівня інформаційно-аналітичного забезпечення управління, що є необхідною умовою розвитку аграрного сектора економіки.

Висновок. Ефективне управління, цілеспрямоване відтворення та повноцінне використання ресурсів аграрних підприємств можуть бути забезпечені тільки тоді, коли мають місце: поперше, економічно та соціально доцільне співвідношення ресурсів праці і матеріальнотехнічної бази, насамперед, основних виробничих фондів; по-друге, застосування прогресивних, високопродуктивних та екологобезпечних технологій у виробництві продукції; по-третє, розширення, відтворення та оновлення ресурсів. Адже чітко організоване, своєчасне та в достатній кількості матеріально-технічне забезпечення i висока якість матеріально-технічних основних засобів виробництва продукції безпосередньо визначають результативність і безпечність функціонування ресурсного потенціалу підприємств, а також їх розвиток.

тва: формування та оцінка : навч. посібник / Н. С. Краснокутська. - К. : Центр навчальної літератури, 2012. - 352 с.

5. Мягких I. M. Аналіз та оцінка використання ресурсного потенціалу в системі споживчої кооперації / I. М. М'яких // Актуальні проблеми економіки. - 2013. - №1(91). - С. 136-142.

6. Романовська Ю. А. Критерії оцінювання розвитку стратегічного потенціалу підприємства // Економіка: проблеми теорії та практики : зб. наук. праць. - Дніпропетровськ : ДНУ, 2011. C. 51-59.

7. Рульєв В.А. Менеджмент : навч. посіб. / В. А. Рульєв, С. О. Гуткевич. - К. : Центр учбової літератури, 2011. - 312 с. 